\title{
PERBANDINGAN HASIL BELAJAR SISWA ANTARA PEMBERIAN TUGAS KELOMPOK DAN TUGAS INDIVIDU PADA MATA PELAJARAN MATEMATIKA DI SMP NEGERI 6 SITUBONDO TAHUN PELAJARAN 2017/2018
}

\author{
${ }^{1}$ Susanti Tefa, ${ }^{2}$ Darsih Idayani, ${ }^{3}$ Tri Astindari \\ STKIP PGRI Situbondo \\ 1 santitefa123@gmail.com, 2darsihidayani@stkippgri-situbondo.ac.id, \\ 3 triaswiji01@gmail.com
}

\begin{abstract}
ABSTRAK
Penelitian ini bertujuan untuk untuk mengetahui perbandingan hasil belajar siswa antara pemberian tugas kelompok dan tugas individu pada mata pelajaran matematika di SMP Negeri 6 Situbondo tahun ajaran 2017/2018. Metode penelitian eksperimen yang digunakan dalam penelitian ini adalah metode eksperimen semu. Populasinya adalah seluruh siswa kelas VIII SMP Negeri 6 Situbondo semester genap tahun ajaran 2017/2018. Teknik pengambilan sampel yang digunakan adalah sampel jenuh karena jumlah siswa dibawah 100 dan dikategorikan dalam sampel kecil dengan jumlah sampel adalah 44 siswa. Instrumen penelitian yang digunakan adalah angket siswa yaitu angket tugs individu dan angket tugas kelompok. Analisis data yang digunakan adalah uji- $t$ (uji beda). Hasil penelitian menunjukkan rata-rata nilai post test kelas kontrol yang diberi tugas individu sebesar 73,18. Sedangkan rata-rata nilai post test kelas eksperimen yang diberi tugas kelompok adalah 76,36. Hasil tersebut menunjukkan bahwa ada perbedaan yang signifikan antara hasil belajar kelas kontrol dan kelas eksperimen dengan selisih 3,18. Jika dilihat dari rata-rata yang ada siswa yang diberi tugas kelompok mendapatkan hasil belajar yang lebih baik dibandingkan siswa yang diberi tugas individu, dengan $t_{\text {hitung }}-1,764<1,682$ dan signifikansi 0,035 0,05.
\end{abstract}

Kata Kunci: hasil belajar, tugas individu, tugas kelompok, uji-t.

\begin{abstract}
This study aims to determine the comparison of student learning outcomes between assignment of group tasks and individual tasks on mathematics subjects in Junior High School 6 Situbondo academic year 2017/2018. Experimental research methods that used in this study is a quasiexperimental method. Population in this experiment is all students of class VIII Junior High School 6 Situbondo semester of academic year 2017/2018. The sampling technique used is the saturated
\end{abstract}


sample because the number of students under 100 and categorized in a small sample with the number of samples is 44 students. The research instrument that the researcher use is student questionnaire that is questionnaire individual task and group task questionnaire, and data analysis used is $t$-test (difference test). The result showed that the average of post test of control class students assigned by individual was 73,18 . Whereas the average post test of the experimental class assigned to the group were 76,36 . These results indicate that there is a significant difference between control class learning outcomes and experimental class with a difference of 3,18 , when viewed from the average that there are students who are given group assignment get better learning outcomes than students assigned individuals, with the result of $t$ count $-1,764<1,682$ and the significance of $0,035<0,05$.

Keywords: learning outcomes, individual tasks, group tasks, t-test.

\section{PENDAHULUAN}

Matematika merupakan ilmu yang mendasari perkembangan teknologi modern yang mempunyai peran penting dalam berbagai disiplin ilmu dan dapat mengembangkan daya pikir manusia. Mata pelajaran matematika perlu diberikan kepada semua peserta didik untuk membekali mereka dengan kemampuan berpikir logis, analitis, sistematis, kritis, kreatif, dan kemampuan bekerja sama yang efektif.

Berdasarkan hasil observasi, diperoleh fakta bahwa sebagian besar siswa masih mengalami kesulitan dalam belajar matematika. Beberapa siswa tidak bersemangat untuk memperhatikan penjelasan guru dalam pembelajaran. Pembelajaran matematika masih berorientasi pada keaktifan guru sehingga siswa terkesan menunggu materi yang diberikan oleh guru saja tanpa ada usaha untuk mencari sendiri materi yang perlu dipelajari.

Hasil belajar merupakan tolok ukur yang menentukan tingkat keberhasilan siswa dalam memahami materi pelajaran. Hasil belajar dapat diukur dengan tes dan dinyatakan dalam bentuk nilai. Rendahnya hasil belajar matematika siswa diindikasikan dengan tidak tercapainya Kriteria Ketuntasan Minimal (KKM).

Terdapat beberapa penelitian yang telah membahas mengenai perbedaan hasil belajar antara siswa yang diberi tugas kelompok dan individu. Penelitian yang dilakukan oleh Bahjatul Fuah (2017) menunjukkan bahwa terdapat perbedaan hasil belajar antara penggunaan metode pemberian tugas kelompok dan menggunakan metode pemberian tugas individu. Penelitian yang dilakukan oleh Dyah Prita Mustika Dira (2017) menunjukkan bahwa terdapat pengaruh yang berarti dalam penggunaan metode pemberian tugas kelompok dan tugas individu terhadap hasil belajar siswa. Penelitian yang dilakukan oleh Haeriyah Arianti Syahrir (2017) menunjukkan bahwa hasil belajar siswa yang diberi tugas kelompok nilai rata-ratanya adalah 75,53. Sedangkan hasil belajar siswa yang diberi tugas individu memperoleh nilai rata-rata 51,50.

Penelitian-penelitian tersebut di atas menunjukkan bahwa metode pemberian tugas yang kurang tepat dapat mempengaruhi hasil belajar yang diraih siswa. Pemberian tugas dapat berupa tugas kelompok atau tugas individu. Pemberian tugas kelompok menitikberatkan pada interaksi antar siswa dalam suatu kelompok untuk menyelesaikan 
tugas-tugas dengan belajar secara bersama-sama. Sedangkan tugas individu dikerjakan oleh siswa secara mandiri. Kecepatan pengerjaan dan keberhasilan pembelajaran siswa sangat ditentukan oleh kemampuan individu.

Berdasarkan permasalahan di atas, peneliti melakukan penelitian mengenai perbandingan antara pemberian tugas kelompok dan individu dengan judul "Perbandingan Hasil Belajar Siswa antara Pemberian Tugas Kelompok dan Tugas Individu pada Mata Pelajaran Matematika di SMP Negeri 6 Situbondo Tahun Pelajaran 2017/2018.

\section{METODE}

\section{Rancangan Penelitian}

Penelitian ini merupakan penelitian kuantitatif. Metode penelitian kuantitatif menurut Sugiyono (2015: 14), yaitu metode penelitian yang berlandaskan filsafat positifisme yang digunakan dalam meneliti sampel dan populasi penelitian. Tenik pengambilan sampel dilakukan dengan acak atau random sampling. Sedangkan pengumpulan data dilakukan dengan menggunakan instrumen penelitian. Analisis data bersifat kuantitatif yang dilakukan dengan tujuan untuk menguji hipotesis yang ditetapkan sebelumnya.

\section{Lokasi Penelitian}

Penelitian ini dilakukan di SMP Negeri 6 Situbondo. Alasan memilih lokasi tersebut adalah karena secara geografis terletak di daerah pedesaan dimana tingkat kesadaran masyarakat akan pentingnya pendidikan masih kurang. Hal ini bisa mempengaruhi cara dan kebiasaan belajar siswa di sekolah. Rendahnya motivasi siwa dalam belajar matematika juga menjadi alasan dipilihnya sekolah ini menjadi lokasi penelitian. Selain itu, sebelumnya belum pernah diadakan penelitian sejenis.

\section{Responden Penelitian}

Teknik penentuan responden yang digunakan dalam penelitian ini adalah teknik penentuan secara populatif dengan teknik pengambilan sampel adalah sampling jenuh. Menurut Sugiyono, teknik sampling jenuh adalah teknik penentuan sampel bila semua anggota populasi digunakan sebagai sampel (2001: 61). Hal ini sering dilakukan bila jumlah populasi relatif kecil, yaitu kurang dari 30 orang. Istilah lain sampling jenuh adalah sensus, dimana semua anggota populasi dijadikan sampel.

\section{Pengumpulan Data}

Menurut Sutopo (2006), sumber data adalah tempat data diperoleh dengan menggunakan metode tertentu baik berupa manusia, artefak ataupun dokumen-dokumen. Data untuk penelitian diperoleh dari guru mata pelajaran matematika SMP Negeri 6 Situbondo yang berupa dokumen hasil belajar matematika siswa. Hasil belajar diperoleh dari pemberian post test dan pre test dalam bentuk tugas kelompok dan tugas individu.

Teknik pengumpulan data yang digunakan dalam penelitian ini adalah teknik pengumpulan data dengan metode kuesioner (angket) dan dokumen. Menurut Nana Syaodih Sukmadinata (2015: 216), metode kuesioner dan dokumen adalah sebagai beikut.

1) Metode Kuesioner (angket)

Angket atau kuesioner merupakan suatu teknik pengumpulan data secara tidak langsung (peneliti tidak langsung bertanya jawab dengan responden). Instrumen dan alat pengumpulan data pada metode ini berisi sejumlah pertanyaan atau pernyataan yang harus dijawab atau direspon oleh responden.

2) Teknik Dokumen (documentary study) 
Teknik pengumpulan data dengan menghimpun dan menganalisis dokumendokumen, baik dokumen tertulis, gambar maupun elektronik.

\section{Analisis Data}

Arikunto (2010: 211) menyatakan bahwa instrumen yang baik harus memenuhi dua buah persyaratan yaitu valid dan reliabel.

\section{a. Uji Validitas Instrumen}

Ghozali (2009) menyatakan bahwa uji validitas digunakan untuk mengukur sah, atau valid tidaknya suatu kuesioner. Suatu kuesioner dikatakan valid jika pertanyaan pada kuesioner mampu untuk mengungkapkan sesuatu yang akan diukur oleh kuesioner tersebut. Validitas menunjukkan kinerja kuesioner dalam mengukur apa yang diukur. Berbagai macam metode validitas antara lain:

a. Validitas Konstruksi

Suatu kuesioner yang baik harus dapat mengukur dengan jelas kerangka dari penelitian yang akan dilakukan.

b. Validitas Isi

Validitas isi adalah suatu alat yang mengukur sejauh mana kuesioner atau alat ukur tersebut mewakili semua aspek yang dianggap sebagai kerangka konsep.

c. Validitas Prediktif

Validitas prediktif adalah kemampuan dari kuesioner dalam memprediksi perilaku dari konsep.

\section{b. Uji Reliabilitas Instrumen}

Setelah menguji validitas, kemudian diperlukan juga uji reliabilitas. Menurut Purwanto (2008: 196) reliabilitas merupakan kemampuan memberikan hasil pengukuran yang relatif tetap. Untuk menganalisis validitas dan reliabilitas hasil angket pada penelitian ini digunakan SPSS (Statistical Package for the Social Sciences).

\section{c. Uji-t Perbandingan Hasil Belajar antara Pemberian Tugas Kelompok dan Tugas Individu}

Uji-t digunakan untuk melihat bagaimana perbandingan hasil belajar antara pemberian tugas kelompok dan tugas individu. Rumus uji- $t$ menurut Sugiyono (2017:138) adalah sebagai berikut.

1. Separated varians

Separated varians merupakan uji-t yang digunakan untuk varian data yang berbeda.

$$
t=\frac{\overline{\mathrm{X}}_{1}-\overline{\mathrm{X}}_{2}}{\sqrt{\frac{\mathrm{s}_{1}^{2}}{\mathrm{n}_{1}}+\frac{\mathrm{s}_{2}^{2}}{\mathrm{n}_{2}}}}
$$

2. Polled varians

Polled varians merupakan uji t yang digunakan untuk varian data yang sama.

$$
t=\frac{\overline{\mathrm{X}}_{1}-\overline{\mathrm{X}}_{2}}{\sqrt{\frac{\left(\mathrm{n}_{1}-1\right) \mathrm{S}_{1}^{2}+\left(\mathrm{n}_{2}-1\right) \mathrm{S}_{2}^{2}}{\mathrm{n}_{1}+\mathrm{n}_{2}-2}\left(\frac{1}{\mathrm{n}_{1}}+\frac{1}{\mathrm{n}_{2}}\right)}}
$$

\section{HASIL DAN PEMBAHASAN}

\section{Hasil}

\section{Penyajian Data}


Dibawah ini adalah temuan penelitian yang diperoleh dari lokasi penelitian. Data hasil belajar yang digunakan berupa nilai pre test dan post test dari siswa kelas VIII A (kelas kontrol) yang diberi tugas individu dan kelas VIII B (kelas eksperimen) yang diberi tugas kelompok di SMP Negeri 6 Situbondo.

Tabel 4.1: Distribusi Frekuensi Data Pre Test Kelompok Kontrol dan Eksperimen.

\begin{tabular}{|c|c|c|c|}
\hline Kelas Ke & Nilai Pre Test & Batas Kelas & Frekuensi $\left(f_{i}\right)$ \\
\hline 1 & $50-54$ & $49.5-54,5$ & 13 \\
\hline 2 & $55-59$ & $54.5-59.5$ & 11 \\
\hline 3 & $60-64$ & $59.5-64.5$ & 8 \\
\hline 4 & $65-69$ & $64.5-69.5$ & 12 \\
\hline Total & 2.515 & 2.515 & 44 \\
\hline Mean & \multicolumn{3}{|c|}{57,2} \\
\hline Modus & 50 \\
\hline Median & \multicolumn{3}{|c}{55.5} \\
\hline
\end{tabular}

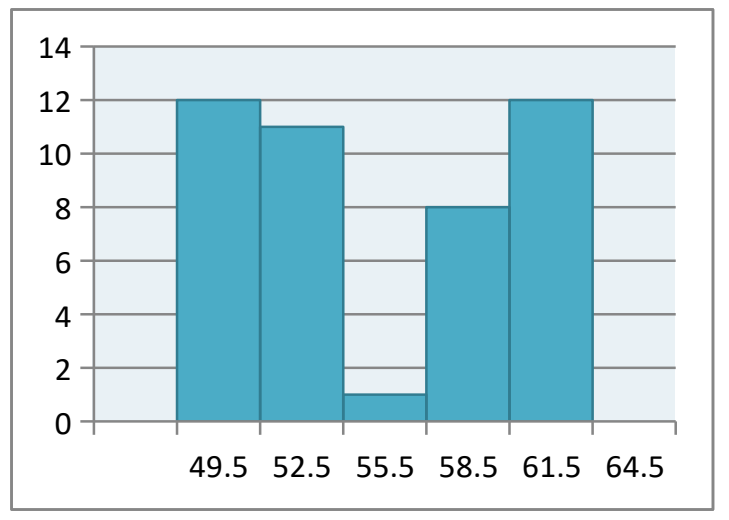

Gambar 4.1: Histogram Pre Test.

Tabel 4.2: Distribusi Frekuensi Data Post Test Kelompok Kontrol dan Eksperimen.

\begin{tabular}{|c|c|c|c|}
\hline Kelas Ke & Nilai Post test & Batas Kelas & Frekuensi $\left(f_{i}\right)$ \\
\hline 1 & $65-69$ & $64.5-69,5$ & 4 \\
\hline 2 & $70-74$ & $69.5-70.5$ & 13 \\
\hline 3 & $75-79$ & $70.5-79.5$ & 15 \\
\hline 4 & $80-84$ & $79.5-84.5$ & 2 \\
\hline 5 & $85-89$ & $84.5-89.5$ & 10 \\
\hline Total & 3.290 & 3.290 & 44 \\
\hline Mean & \multicolumn{3}{|c|}{74,8} \\
\hline Modus & 70 \\
\hline Median & 70.5 \\
\hline
\end{tabular}




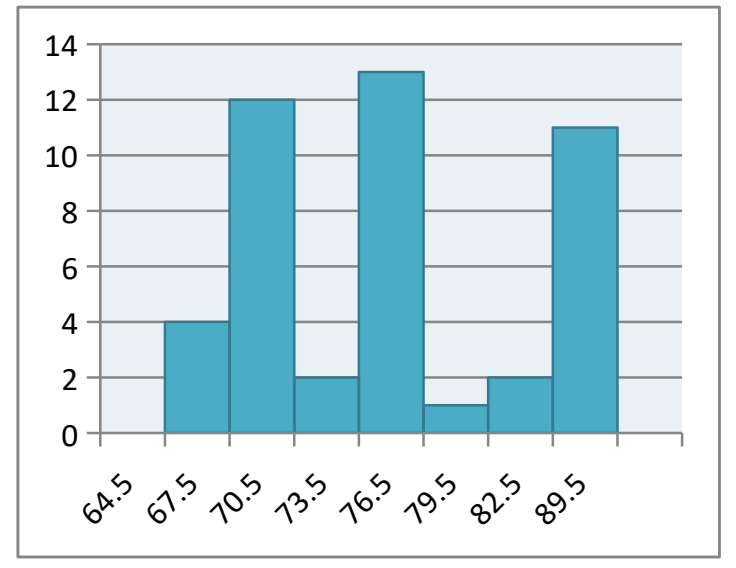

Gambar 4.2: Histogram Post Test.

\section{Uji Validitas dan Reliabilitas}

\section{a. Uji Validitas}

Untuk mengetahui apakah data hasil angket yang diperoleh sudah valid dan reliabel, dapat digunkan rumus umum product moment:

$r_{x y}=\frac{N \sum X Y-\sum X \sum Y}{\sqrt{\left(N \sum X^{2}-\left(\sum X\right)^{2}\right)\left(N \sum Y^{2}-\left(\sum Y\right)^{2}\right)}}$

Untuk mengetahui apakah hasil analisis angket valid atau tidak, dapat dilihat dari nilai $r_{\text {hitung }}$ yang kemudian dibandingkan dengan nilai $r_{\text {tabel }}$ dengan derajat kebebasan $\mathrm{df}=\mathrm{n}-2$. Suatu angket dapat dikatakan valid apabila nilai $r_{\text {hitung }} \geq$ nilai $r_{\text {tabel }}$. Sebaliknya angket tersebut tidak valid apabila $r_{\text {hitung }}<$ nilai $r_{\text {tabel }}$. Pada uji validitas terdapat 9 item yang tidak valid pada masing-masing angket, baik angket tugas individu maupun angket tugas kelompok.

\section{b. Uji Reliabilitas}

Berdasarkan syarat untuk melakukan uji reliabilitas, terlebih dahulu item angket yang tidak valid tersebut harus dihapus. Setelah item angket yang tidak valid dihapus, analisis dapat dilanjutkan. Suatu angket dapat dikatakan reliabel apabila nilai cronbach alpha $\geq 0,6$.

Tabel 4.7: Reliability Statistics Kelompok

\begin{tabular}{|r|r|r|}
\hline $\begin{array}{c}\text { Cronbach' } \\
\text { s Alpha }\end{array}$ & $\begin{array}{c}\text { Cronbach's Alpha } \\
\text { Based on } \\
\text { Standardized Items }\end{array}$ & $\begin{array}{c}\text { N of } \\
\text { Items }\end{array}$ \\
\hline .734 & .874 & 22 \\
\hline
\end{tabular}


Tabel 4.8: Reliability Statistics Individu

\begin{tabular}{|r|r|r|}
\hline $\begin{array}{c}\text { Cronbach's } \\
\text { Alpha }\end{array}$ & $\begin{array}{c}\text { Cronbach's Alpha } \\
\text { Based on } \\
\text { Standardized Items }\end{array}$ & $\begin{array}{c}\text { N of } \\
\text { Items }\end{array}$ \\
\hline .730 & .861 & 22 \\
\hline
\end{tabular}

Berdasarkan hasil analisis yang ada pada Tabel 4.7 dan Tabel 4.8, cronbach alpha angket kelompok adalah 0,734 $>0,6$ dan cronbach alpha angket individu adalah 0,730 > 0,6 maka angket kelompok dan individu reliabel.

\section{Analisis Perbandingan Hasil Pre Test dan Post Test}

Data hasil belajar berupa pre test dan post test yang disajikan dalam bentuk tabel dan diagram batang untuk mempermudah proses analisis. Analisis data yang digunakan adalah uji- $t$ atau yang lebih sering dikenal dengan istilah uji beda.

Tabel 4.9 Data Pre Test dan Post Test Kelas Kontrol dan Kelas Eksperimen

\begin{tabular}{|c|c|c|c|c|}
\hline \multirow{2}{*}{ Deskripsi Data } & \multicolumn{2}{|c|}{$\begin{array}{c}\text { Kelas VIIIA } \mathrm{n}=22 \\
(\text { Kelas Kontrol) }\end{array}$} & \multicolumn{2}{c|}{$\begin{array}{c}\text { Kelas VIIIB } \mathrm{n}=22 \\
\text { (Kelas Eksperimen) }\end{array}$} \\
\cline { 2 - 5 } & Pre Test & Post Test & Pre Test & Post Test \\
\hline Nilai Rata-Rata & 57,95 & 73,18 & 56,36 & 76,36 \\
\hline Nilai Maksimum & 75 & 90 & 65 & 85 \\
\hline Nilai Minimum & 50 & 65 & 50 & 70 \\
\hline
\end{tabular}

Dari Tabel 4.9 dapat dilihat bahwa rata-rata hasil pre test kelas kontrol adalah 57,95. Sedangkan rata-rata hasil pre test kelas eksperimen adalah 56,36. Terlihat bahwa rata-rata kelas kontrol lebih besar daripada rata-rata kelas eksperimen. Dari Tabel 4.9 juga dapat dilihat bahwa rata-rata hasil post test kelas kontrol 73,18 . Sedangkan rata-rata hasil post test kelas eksperimen adalah 76,36.

Tabel 4.10 Perbandingan Nilai Pre Test Kelas Kontrol dan Kelas Eksperimen

\begin{tabular}{|c|c|c|c|}
\hline \multirow{2}{*}{ No } & \multirow{2}{*}{ Nilai } & \multicolumn{2}{c|}{ Frekuensi } \\
\cline { 3 - 4 } & & Kontrol & Eksperimen \\
\hline 1 & 50 & 5 & 8 \\
\hline 2 & 55 & 4 & 7 \\
\hline 3 & 60 & 8 & 0 \\
\hline 4 & 65 & 5 & 7 \\
\hline \multicolumn{2}{|c|}{ Jumlah } & 22 & 22 \\
\hline \multicolumn{2}{|c|}{ Rata-rata } & 57,95 & 56,36 \\
\hline NilaiTertinggi & 65 & 65 \\
\hline \multicolumn{2}{|c|}{ NilaiTerendah } & 50 & 50 \\
\hline
\end{tabular}




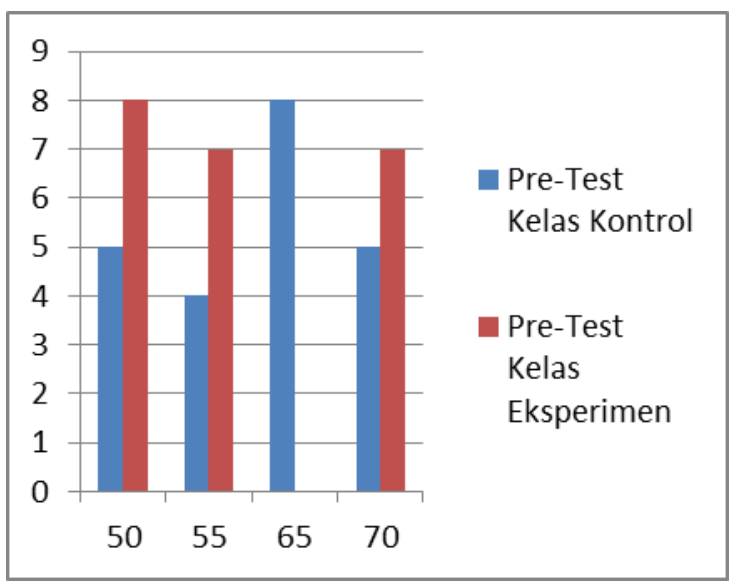

Gambar 4.1: Diagram Perbandingan Hasil Pre Test Kelas Kontrol dan Eksperimen

Tabel 4.11: Perbandingan Nilai Post Test Kelas Kontrol dan Kelas Eksperimen

\begin{tabular}{|c|c|c|c|}
\hline \multirow{2}{*}{ No } & \multirow{2}{*}{ Nilai } & \multicolumn{2}{|c|}{ Frekuensi } \\
\cline { 3 - 4 } & & Kontrol & Ekperimen \\
\hline 1 & 65 & 4 & 0 \\
\hline 2 & 70 & 6 & 8 \\
\hline 3 & 75 & 9 & 7 \\
\hline 4 & 85 & 3 & 7 \\
\hline \multicolumn{2}{|c|}{ Jumlah } & 22 & 22 \\
\hline \multicolumn{2}{|c|}{ Rata-rata } & 73.18 & 76.36 \\
\hline Nilai Tertinggi & 85 & 85 \\
\hline Nilai Terendah & 65 & 70 \\
\hline \multicolumn{2}{r}{} \\
\hline
\end{tabular}

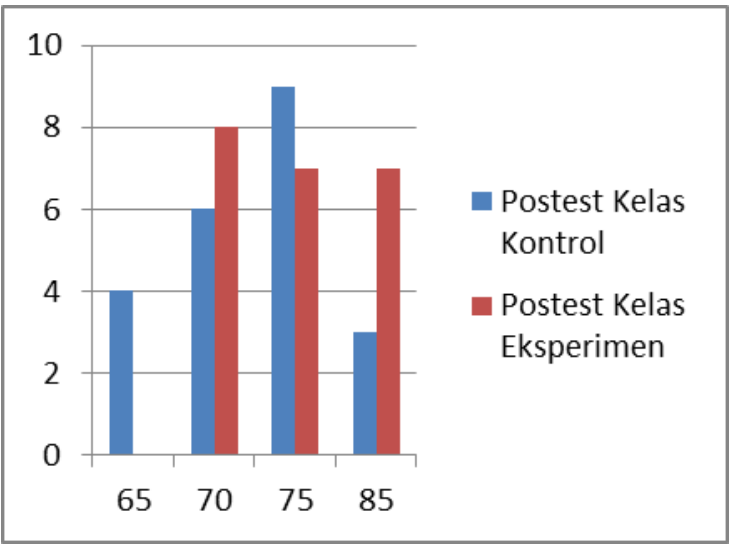

Gambar 4.2: Diagram Perbandingan Hasil Post Test Kelas Kontrol dan Eksperimen 


\section{Pengujian Hipotesis}

\section{a. Uji-t Pre Test dan Post Test Kelas Kontrol}

Tabel 4.12: Uji- $t$ Pre Test dan Post Test Kelas Kontrol

\begin{tabular}{|c|c|c|c|c|c|}
\hline \multirow{2}{*}{ Kelas kontrol } & \multirow{2}{*}{ Rata-rata } & \multicolumn{4}{|c|}{$\mathrm{T}$ Test For Equality Of Means } \\
\cline { 3 - 6 } & & $\mathrm{t}_{\text {hitung }}$ & $\mathrm{t}_{\text {tabel }}$ & Sig. & Selisih \\
\hline Pretes & 57.95 & \multirow{2}{*}{-0.816} & 1.6820 & 0.000 & 15.23 \\
\hline Postes & 73.18 & & &
\end{tabular}

Berdasarkan hasil analisis menggunakan SPSS, didapatkan hasil $t_{\text {hitung }}$ adalah $-0,816<$ $\mathrm{t}_{\text {tabel }} 1,6820$, dan nilai signifikansi $0,000<0,005$.

\section{b. Uji- $t$ Pre Test dan Post Test Kelas Eksperimen}

Tabel 4.13: Uji-t Pre Test dan Post Test Kelas Eksperimen

\begin{tabular}{|c|c|c|c|c|c|}
\hline \multirow{2}{*}{$\begin{array}{c}\text { Kelas } \\
\text { eksperimen }\end{array}$} & \multirow{2}{*}{ Rata-rata } & \multicolumn{4}{|c|}{ T Test For Equality Of Means } \\
\cline { 3 - 6 } & & $\mathrm{t}_{\text {hitung }}$ & $\mathrm{t}_{\text {table }}$ & Sig. & Selisih \\
\hline Pre Test & 56.36 & \multirow{2}{*}{-10.371} & 1.6820 & 0.000 & 20 \\
\hline Post Test & 76.36 & & & \\
\hline
\end{tabular}

Sama dengan hasil analisis pada kelompok kontrol, pada kelompok eksperimen juga dilakukan analisis menggunakan SPSS didapatkan hasil $t_{\text {hitung }}$ adalah $-10,371<t_{\text {tabel }}$ 1,6820 dan nilai signifikansi $0,000<0,005$.

\section{c. Uji Gain antara Pemberian Tugas Kelompok dan Tugas Individu}

Di bawah ini merupakan hasil analisis hasil belajar dengan mengunakan software SPSS.

Tabel 4.14: Uji- $t$ Pre Test Kelas Eskperimen dan Kontrol

\begin{tabular}{|c|c|c|c|c|c|}
\hline \multirow{2}{*}{ Pre Test } & \multirow{2}{*}{ Rata-rata } & \multicolumn{4}{|c|}{ T Test For Equality Of Means } \\
\cline { 3 - 6 } & & $\mathrm{t}_{\text {hitung }}$ & $\mathrm{t}_{\text {tabel }}$ & Sig. & Selisih \\
\hline Kontrol & 57.95 & \multirow{2}{*}{885} & 1.6820 & 0.381 & 1.59 \\
\hline Eksperimen & 56.36 & & & \\
\hline
\end{tabular}

Dari Tabel 4.14 di atas diketahui nilai $t_{\text {hitung }}$ adalah 885 , dan nilai $t_{\text {tabel }}$ adalah 1,6820 dengan derajat kebebasan $\mathrm{df}=42$ dan nilai signifikansi adalah sebesar $0,381>0,05$

Tabel 4.15 Uji-t Post Test Kelas Eskperimen dan Kontrol

\begin{tabular}{|c|c|c|c|c|c|}
\hline \multirow{2}{*}{ Postes } & \multirow{2}{*}{ Rata-rata } & \multicolumn{4}{|c|}{ T Test For Equality Of Means } \\
\cline { 4 - 6 } & & t hitung & t tabel & Sig. & Selisih \\
\hline Kontrol & 73.18 & \multirow{2}{*}{-1.764} & 1.6820 & 0.035 & 3.18 \\
\hline Eksperimen & 76.36 & & & \\
\hline
\end{tabular}

Hasil perhitungan post test pada Tabel 4.15 menunjukkan nilai $t_{\text {hitung }}-1,764<$ 1,6820 dengan derajat kebebasan $\mathrm{df}=42$. Sedangkan nilai signifikansinya adalah $0,035>$ 0,05 . Berdasarkan hasil tersebut, dilihat dari nilai signifikansinya yang lebih kecil dari 
0.05, maka dikatakan $\mathrm{H}_{0}$ ditolak atau $\mathrm{Ha}$ diterima. Maka dapat disimpulkan bahwa ada perbedaan hasil belajar siswa yang siginifikan antara yang diberi tugas kelompok dan tugas individu.

\section{Pembahasan}

Hasil pre test menunjukkan rata-rata dari kedua kelas yang relatif sama. Kelas kontrol adalah 57,95. Sedangkan kelas eksperimen adalah 56,36 yang hanya memiliki selisih angka sebesar 1,59. Setelah dilakukan pembelajaran dengan menggunakan metode pemberian tugas individu pada kelas kontrol dan pemberian tugas kelompok pada kelas eksperimen, diperoleh nilai rata-rata post test kelas kontrol adalah 73,18 dan rata-rata post test kelas eksperimen adalah 76,36 dengan selisih 3,18.

Selain dilihat dari rata-rata hasil belajar kedua kelas, bukti lain yang menunjukkan bahwa ada perbedaan antara hasil belajar siswa yang diberi tugas kelompok dan tugas individu ditunjukkan oleh nilai signifikansi yaitu $0.035<0.05$, dimana sesuai dengan dasar pengambilan keputusan, apabila nilai signifikansi dari hasil analisis lebih kecil dari 0,05, maka dikatakan $\mathrm{H}_{0}$ ditolak atau Ha diterima dan dinyatakan ada perbedaan yang signifikan antara pemberian tugas secara kelompok dan tugas secara individu.

\section{PENUTUP}

\section{Kesimpulan}

Berdasarkan pembahasan sebelumnya, didapatkan hasil rata-rata kelas eksperimen lebih besar dibandingkan rata-rata kelas kontrol yaitu $76.36>73.18$, sehingga dapat disimpulkan bahwa hasil belajar siswa yang diberi tugas secara kelompok lebih baik dibandingkan dengan hasil belajar siswa yang diberi tugas secara individu.

\section{Saran}

Berdasarkan hasil dan pembahasan di atas, terdapat beberapa saran yang dapat dipertimbangkan, yaitu:

1. Bagi guru, disarankan untuk menggunakan metode pemberian tugas secara kelompok, khususnya dalam pembelajaran matematika. Hal ini dikarenakan ada pengaruh positif yang terjadi dalam penerapan metode tersebut.

2. Bagi pembaca disarankan untuk melakukan penelitian lebih lanjut terkait penelitian ini untuk melengkapi kekurangan yang ada.

\section{DAFTAR PUSTAKA}

Arikunto, S. (2010). Prosedur Penelitian (Suatu Pendekatan Praktik). Jakarta: Rinekan Cipta.

Dira, D. P. M. (2017). Perbedaan Hasil Belajar Matematika antara Tugas Kelompok dan Tugas Individu Siswa Kelas IV SD Negeri Prambanan. Yogyakarta: Universitas Negeri Yogakarta.

Fuah, B. (2017). Perbandingan Hasil Belajar Siswa antara Pembelajaran dengan Menggunakan Metode Tugas Kelompok dan Tugas Individu dalam Mata Pelajaran Matematika di Madrasah Ibtidaiyah Negeri Kebun Bunga Banjarmasin. Banjarmasin: Universitas Islam Negeri Antasari.

Ghozali, I. (2009). Aplikasi Analisis Multivariate Dengan Program SPSS. Semarang: Universitas Diponegoro. 
Syahrir, A. H. (2017). Perbandingan Hasil Belajar Matematika antara Peserta Didik yang Diberi Tugas Kelompok dengan Tugas Individu di Kelas IX MTs. Madani Alauddin Paopao Kabupaten Gowa. Makassar: Universitas Islam Negeri.

Sugiyono. (2001). Metode Penelitian Administrasi. Bandung: Alfabeta.

Sugiyono. (2015). Metode Penelitian Kuantitatif, Kualitatif, dan Kombinasi (Mixed Method). Bandung: Alfabeta.

Sugiyono. (2017). Statistika Untuk Penelitian. Bandung: Alfabeta.

Sukmadinata, S. N. (2015). Metode Penelitian Pendidikan. Bandung: PT. Remaja Rosdakarya.

Sutopo. (2006). Metode Penelitian Kualitatif. Surakarta: Universitas Sebelas Maret. 